\title{
Evaluation of English Textbooks in Terms of Textuality Standards
}

\author{
Gürbüz Ocak ${ }^{1}$, Emine Akkaş Baysal ${ }^{2}$ \\ ${ }^{1}$ Faculty of Education, Afyon Kocatepe University, Afyonkarahisar, Turkey \\ ${ }^{2}$ Fatih Anatolian High School, Afyonkarahisar, Turkey \\ Correspondence: Gürbüz Ocak, University of Afyon Kocatepe, Faculty of Education, Department of Educational \\ Sciences Curriculum and Teaching, Afyonkarahisar, Turkey.
}

Received: September 26, 2016

doi:10.11114/jets.v4i12.1897

\author{
Accepted: October 10, 2016 \\ Online Published: October 28, 2016 \\ URL: http://dx.doi.org/10.11114/jets.v4i12.1897
}

\begin{abstract}
Putting a number of sentences together in order to build a text, the sentences must comply with the criteria such as cohesion, coherence, intentionality, acceptability, contextualization, informativeness and intertextuality. The text should bear these criteria in order to fulfil the intended communicative features. Therefore, in this study, it is aimed to develop "The Text Evaluation Rubric" and to evaluate the texts in the 9th grade English textbooks by means of this rubric. For this purpose, relevant literature has been searched and a rubric with seven dimensions and including textuality criteria has been prepared. To ensure the content validity of the rubric, experts have been consulted. The weighted Kappa Coefficient was examined for reliability. In terms of dimensions of the rubric, the reliability value of Cohesion dimension is .596; that of Coherence dimension is .917; that of Intentionality is .882; that of Acceptability is .851; that of Contextualization is .948 ; that of Informativeness is .875 and that of Intertextuality is .880 . Moreover, the validity of rubric is provided by inspection of content, structure and extent. These results show that "The Text Evaluation Rubric" developed to evaluate the texts is a reliable and valid rubric. This rubric can be an alternative tool to evaluate the texts being in high school English textbooks.
\end{abstract}

Keywords: text, textuality, English textbooks, rubric

\section{Introduction}

\subsection{Introduce the Problem}

In the most general sense, a text is a set of words that make up a format, narrative and punctuation features (TDK, 2011). Akbayır (2007) expresses how if a fabric takes shape by weaving the ropes as a whole, similarly, a text is made up by adding the elements which build the text one after the other. A text is a system which is composed of interconnected elements generated by people as oral or written in a particular context (Günay, 2007). Güllü (1994) defines a text as a passage which can be in various length, oral or written and evokes a unity.

Text linguistics, dealing with text as a study subject, is a discipline explaining the general rules and conditions for creating text and studying the importance of them (Şenöz, 2005). Text linguistics examines the structure of the texts, provides clues to be understood or interpreted and allows sound footing in terms of text context (Oraliş \& Özil, 1992).

The purpose of text linguistics is to investigate how the parts of the text create a text with linear and semantic continuity. How appropriateness or inappropriateness of a sentence in terms of grammar can be detected, similarly, the texts can be distinguished from non-text sentence blocks by means of criteria generated as a result of text linguistics studies (Onursal, 2003).

It is stated that according to text linguistics, texts should include these seven criteria in order to have communicative function; cohesion, coherence, intentionality, acceptability, contextualization, informativeness, intertextuality (Beaugrande \& Dressler, 1981). When one of these is inefficient, the communicative function of the text doesn't work properly.

Cohesion: It deals with whether the words and sentences in a text connect to each other in a sequence. Cohesion comes out with connections generated with the grammatical relations within the surface structure of the text. The relation between the deep structures of linguistic units is defined as cohesion (Kılıç, 2002).

Halliday and Hasan (1976) state there is one specific kind of meaning relation that is critical for the creation of texture: 
that in which one element is interpreted by reference to another. What cohesion has to do with is the way in which the meaning of the elements in interpreted. Where the interpretation of any item in the discourse requires making reference to some other item in the discourse, there is cohesion. Cohesion defines sentence components of a text; for instance, it generally handles with the words we use or hear in terms of grammar and lexicology (Carstens, 1997). De Beaugrande and Dressler (1981) say that cohesion is the combination of sentence elements grammatically.

Cohesion mentions what kind of grammatical rules are used to create a text (Akbayır, 2007). All new words added to text receive support from the information previously provided by these words in the text, however, it adds new information to the text itself (Günay, 2007). Cohesion provides unity between not only the sentences also the paragraphs which are related to surface structure of the text. Hence, when the text forms completeness, it also requires that smaller units in the text should be corresponded with each other (Can, 2012).

Cohesion can be analysed under two main headings; "referential cohesion" and "formal-lexical cohesion"; however, Uğur (2012) states four; reference, ellipsis, substitution and conjunctions.

Reference: Instead of repeating a word used in the text, using another word, phrase, suffix or prefix representing it generates reference. Cohesion itself is located later on the reference; in other words, it happens when the same things take place for the second time in the text (Halliday \& Hasan, 1976).

Ellipsis: Ellipsis is physically deletion of the elements in the same sentence because writer believes that reader will add the missing element in the sentence (Donnelly, 1994).

Substitution: Substitution happens when an element of a text displaces another element of that. Substitution is mostly a grammatical function generating between the words; in other words, it doesn't generally concentrate on meaning (Uğur, 2012). Moreover, it allows the text to become shorter (Donnelly, 1994).

Conjunctions: It refers not only connectors but also some adverbs and prepositions. Connector type words and connector function words are used to ensure cohesion-cohesive.

Coherence is defined as the relationship between the sentences and paragraphs (Coşkun, 2007). Karatay (2010) states coherence creates semantically scheme of information in mind and it takes shape around the topic processed in the text. In terms of the ability to create text, coherence bases on the logical order and connection between the parts of the text (Özkan, 2004). Coherence is a situation in which there isn't any lack feeling or thought processed in text; on the contrary, there is a harmony between them (Çeçen, 2009). Coherence changes and develops depending upon the mental ability of reader. The pattern of events and facts in a text activates coherence (Karatay, 2010). Hatch (1992) defines coherence as the unity of sentence elements being in a harmony. McCarthy (1991) stresses coherence doesn't mean separated sentences; on the contrary, it refers the sentences hanging on each other. In this way, the textuality criteria complete each other in terms of text and reader (Ülper, 2011). Coherence involves the logical patterns between the propositions, the semantic and grammatical relations. It reveals the configuration of the target text (Taşı̈üzel, 2004 \& Toklu, 2003).

If a text forms completeness from beginning to end, has a logical plan, not mention contradictory statements, contributes to previous thought, gives the necessary information to the reader in order to help him/her understand well, it can be said that it is a coherent text (Coşkun, 2005, pp. 101-105). Neubert and Shreve (1992) state a coherent text is a logical construct and guide the reader throughout the text.

Intentionality: It means revealing the target message which the writer wants to explain to the reader (Lüle Mert, 2011). There should be a harmony in terms of semantic and logic throughout the text (Uğur, 2012)

Acceptability: It is generally thought as a pair of principles. In any type of the text, there are producers who intend to generate a piece of information. The reader is eager to accept the text which is submitted as a communicative text (Carstens, 1997).

Contextualization: It refers to the subject of text, aim and the type of text (Lüle Mert, 2011). It is related to environment where the text is and the attributed meaning to it by people using language (Uğur, 2012).

Informativeness: The text needs to include both previous and new information in a balanced manner in order to be successful in arousing the reader's interest to the text (Lüle Mert, 2011). It is related to previously known or unknown information being in the text by the reader (Uğur, 2012).

Intertextuality: It is the least grammatical criteria among the other textuality criteria. It should generally be dealt with the literary studies together. The configuration of a text and being understood of it are impressed by another similar text (Carstens, 1997).

Texts are important in teaching language. Teaching language centres around the texts. The quality of reading texts and the usage of them take an important place in teaching grammar and transmissing culture (Şimşek, 2011). 
Texts are important materials for bringing out a combination of the words and grammar rules as a whole. For this reason, the importance of texts used in learning and teaching a foreign language is undeniable. While learning a foreign language, students generally meet the texts in classroom environment as a course material. This situation raises the importance of course materials. Thus, a taxonomy of criteria for evaluating o good textbook is extremely important. The texts which will be used in lessons should be an appropriate level for the target group, suited to the aim of the lesson and reflect the characteristics of language and cultural values. They should create a real-like environment for students. Moreover, the usage of text is so important that students can develop their reading comprehension skills, speaking skills and vocabulary knowledge (Serin \& Turan, 2015).

The basic characteristic of a qualified text is being prepared in accordance with the criteria of textuality. Besides, having the qualification of the text type such as a poem, letter or news is extremely important. For this reason, each text is an example of a certain text type (Brinkler, 1988). Having full knowledge of the whole rules and machinery of a language isn't sufficient to compresence and generate in mother or foreign language. In addition to grasping the rules of a language and machinery of them, knowing the characteristic of a text type is quite important (Ayata-Şenöz, 2005). In this context, having the textuality criteria in order to ensure effectiveness and functionality of teaching-learning language is substantial for the texts in 9th grade English textbooks. In the light of these, in this study it is aimed to develop "The Text Evaluation Rubric" and to evaluate the texts in the 9th grade English textbooks by means of this rubric.

\subsection{Explore Importance of the Problem}

Texts are important materials for bringing out a combination of the words and grammar rules as a whole. For this reason, the importance of texts used in learning and teaching a foreign language is undeniable. While learning a foreign language, students generally meet the texts in classroom environment as a course material. This situation raises the importance of course materials. The basic characteristic of a qualified text is being prepared in accordance with the criteria of textuality. In this context, having the textuality criteria in order to ensure effectiveness and functionality of teaching-learning language is substantial for the texts in 9th grade English textbooks. In the light of these, in this study it is aimed to develop "The Text Evaluation Rubric" and to evaluate the texts in the 9th grade English textbooks by means of this rubric.

\section{Method}

This study was conducted in two stages. At the first stage, texts analysis was carried out in order to develop a rubric to evaluate the texts in English textbooks. This period is called as document analysis in qualitative research. Document analysis is much more effective method than deep interviews and participant observation. It contains the analysis of documents having the information about phenomenon we search (Bailey, 1994). At the second stage, the results obtained from document analysis were digitized. Reliability analysis was done by means of statistical process. This stage of the study enters into quantitative research. This kind of research uses experimental method and expression; thus, it explains the phenomenon using mathematical operations and numeric data (Cohen \& Manion, 1980 \& Creswell, 1994).

\subsection{Identify Subsections}

In this study, it is aimed to develop "The Text Evaluation Rubric" and to evaluate the texts in the 9th grade English textbooks by means of this rubric. In this context, firstly, a detailed literature scanning was carried out. The textuality criteria generated by Beaugrande and Dressler (1981) are widely used (Halliday \& Hassan 1976; Demircan, 1986; Altunkaya, 1987; Aktaş, 1996; Günay, 2007; Koç, 1992; İşsever, 1995; Özkan, 2004; Gee, 1991; Medina, 2003). According to these criteria taken into consideration in this study, the rubric prepared to evaluate the texts in 9th grade English textbooks has seven dimensions. The first one is "cohesion" which examines the relationship between sentences each other and the text; the second one is "coherence" which tries to define whether information in text creates a whole semantically; the third one is "intentionality" which tries to define whether there is a message or not in the text; the next one is "acceptability" which examines whether the text relays information to the target group; the next one is "contextualization" that investigates the appropriateness of the text for readers; the next one is "informativeness" which tries to check whether the text includes previous and new information in a balanced way; the last one is "intertextuality" which deals with whether there is a relationship between the text and the others. These dimensions are defined in the context of an ideal text.

It is thought that using fewer scoring levels in rubrics is more advantageous than using further, because it is easy to make meaningful distinction with fewer scoring level. However, when further scoring levels are used, it is sometimes impossible to make meaningful distinctions between categories. For this reason, in this study the dimensions are scored between 1-4 points (Moskal \& Leydens, 2000; Stevens \& Levi, 2004). Draft rubric was checked by three experts in 
terms of content, grammar structure and criteria. According to their points of view, necessary corrections were carried out and put into the final form. Related to its content, the rubric was called "The Text Evaluation Rubric".

23 texts in 9th grade English textbook were selected randomly in order to apply First of all, the application of rubric was tired on two texts in order to test its practicality; then, 21 texts were evaluated.

While preparing a rubric, firstly, the characteristic, structure and nature of rubric should be examined. Then, whether it has some qualities such as reliability and validity should be specified (Kan, 2007). Two kinds of rubric can be mentioned for rubrics: harmony between the scorers and reliability between the scorers. Harmony between the scorers means the coherency between the scorers after using the rubric. Reliability between the scorers means the correlation between the difference of scorers (Tinsley \& Weiss, 2000). The harmony of scorers can be enhanced by defining the criteria in detailed. Unless there are some instructions, scorers can focus on different points. A well-developed rubric can decrease subjectivity and guide the scorers to target point (Newell, Dahm \& Newell, 2002). Guiding the scorers like this is a requirement for increasing harmony between the scorers (Zimmaro, 2004). A reliable rubric gives the same score in repeated measurement. In other words, if the same rubric is scored by the same scorer again, the scorer gives the same points. This repetition shows harmony between the scorers and the reliability of rubric (Moskal \& Leydens, 2000).

In order to specify harmony between the scorers, lots of methods can be used, because of that it can be sometimes difficult to select the most suitable method. While deciding it, researchers should take into consideration some factors. The first of them can be the scale level of measurement tool. If the data are equal interval scale or equal ratio scale, Krippendorf Alpha statistic can be used (Krippendorf, 2004). If they are ordinal scale, Pearson Correlation isn't suitable; however, correspondence percentage and Cohen's Kappa can be more appropriate (Fleiss \& Cohen, 1973). Another important factor is the number of scorers. If we specify the harmony between two scorers Cohen's Kappa can be used; however, if the harmony between three or more scorers is defined, Fleiss Kappa can be more convenient. Therefore, practicable approaches can be decided. And the last factor can be related to deciding a result using available data (Stoddart, Abrams, Gasper \& Canaday, 2000).

In this study, texts were scored by two independent scorers in order to determine the reliability of rubric. The results of scores were analysed with Cohen's Kappa statistics using two different programme. The data obtained from Cohen's Kappa shows the strength of agreement which are interpreted as" $<0$ Poor; 0.0-0.20 Fair; 0.21-0.40 Moderate; 0.41-0.60 Good; 0.61-0.80 Very Good; 0.81-1.00 Perfect" (Landis \& Koch, 1977).

Moskal and Leydens (2000) state the validity of rubrics should be controlled in terms of content, structure and criterion. Content is related to whether or not evaluation criteria define an irrelevant content; specify all aspects of designed content; determine content area availability of a homework/project which will be evaluated by a rubric. Structure is interested whether or not the whole aspects of the target structure are evaluated by scoring criteria and there is a relationship between all the evaluation criteria and related structure. Criterion sheds lights on how scoring criteria reflect the elements of future success or performance.

In this study, the validity of rubric was examined in terms of content, structure and criterion. Three experts' opinions were obtained. In the light of these opinions, the final form of "The Text Evaluation Rubric" was put into.

\section{Results}

In this part, first of all, there is an example of text evaluation. Then, there are the reliability results of rubric.

Text Evaluation Rubric in English Textbooks - Example Text Evaluation I

Unit 2 Page 27

"In our modern society people live in flats or apartments isolated from the other people. However, there are still some places where people care about each other. They help each other with things like gardening and watering the plants and they also protect their neighbours against criminals. Neighbourhood Watch aims to keep an eye on the houses of the people by patrolling in the area and reporting any suspicious activity to the police. The aim of Neighbourhood Watch includes educating residents of a community on security and safety. The result of this is safe and secure neighbourhoods" (MEB, 2015).

1-Cohesion: At the beginning of the text, it mentions the existence of people living together who isolated himself from society in the modern world. However, it also mentions there are neighbourhood relations in some places and it can go the whole hog with "Neighbourhood Watch". The words and sentences in the text are related to each other. The phrases used in the text are supporting the text discourse. The grammar structures and vocabulary are related to the text discourse. There aren't repeated words; instead of this, there are synonyms or different explanations. There aren't missing or shortened structures that cause to be misunderstood the text. 
2-Coherence: The sentences in the text are related to each other. This relationship creates a scheme in the mind of reader. The text mentions what "Neighbourhood Watch" and the visual mean. The elements of text are related to each other. The pattern of words and sentences constitute a meaningful whole.

3-Intentionality: The text explains clearly what "Neighbourhood Watch" means and it serves the message to readers.

4-Acceptibility: The text has an understandable message for readers. In other words, readers can understand the message directly. Thus, text can be admitted as a communicative one.

5-Contextualization: The manner of telling is appropriate for readers. A 9th grade student having knowledge at A1 level can attribute a meaning and associate with his/her environment.

6-Informativeness: The text excites attention of readers. There are some new phrases in the text for readers. After reading the text, readers have knowledge. Readers are guided to new information (Neighbourhood Watch) by means of vocabulary.

7-Intertextuality: There isn't a relationship between the previous texts and this text directly. However, the relation can be contacted with the text "Sky City".

As in the example above, the other 22 texts were evaluated by Text Evaluation Rubric in English Textbooks and the results are given in the tables below (Table 1 and 2).

Table 1. The Results of Inter-rater Cohen's Kappa in Terms of Dimensions

\begin{tabular}{cccccccc}
\hline & Cohesion & Coherence & Intentionality & Acceptability & Contextualization & Informativeness & Intertextuality \\
\hline$K$ & .596 & .917 & .882 & .851 & .948 & .875 & .880 \\
Number & 23 & 23 & 23 & 23 & 23 & 23 & 23 \\
of Texts & & & & & &
\end{tabular}

There are inter-rater Cohen's Kappa $(\kappa)$ results in Table 1 . The inter-rater Cohen's Kappa $(\kappa)$ value in dimensions were calculated as cohesion .596; coherence .917; intentionality .882; acceptability .851; contextualization .948; informativeness .875 and intertextuality .880 . According to the table presented by Landis and Koch (1977) the strength of agreement is very good.

Table 2. The Mean and Standard Deviation Values in Terms of Dimensions

\begin{tabular}{|c|c|c|c|c|c|c|c|c|c|c|c|c|c|c|}
\hline & \multicolumn{2}{|c|}{ Cohesion } & \multicolumn{2}{|c|}{ Coherence } & \multicolumn{2}{|c|}{ Intentionality } & \multicolumn{2}{|c|}{ Acceptability } & \multicolumn{2}{|c|}{ Contextualization } & \multicolumn{2}{|c|}{ Informativeness } & \multicolumn{2}{|c|}{ Intertextuality } \\
\hline & $\mathrm{X}$ & SS & $X$ & SS & $\mathrm{X}$ & SS & $X$ & SS & $\mathrm{X}$ & SS & $\mathrm{X}$ & SS & $X$ & SS \\
\hline R1 & 4.0 & .00 & 3.6 & .58 & 3.5 & .84 & 2.8 & ,81 & 3,3 & ,87 & 2,4 & 89 & 3,1 & ,62 \\
\hline R2 & 4.0 & .00 & 3.7 & .53 & 3.6 & .83 & 3.0 &, 85 & 3,3 &, 84 & 2,3 & ,92 & 3,1 & 67 \\
\hline Total & 4.0 & .00 & 3.6 & 0.55 & 3.5 & 0.83 & 2.9 & 83 & 3,3 &, 85 & 2,3 &, 90 & 3,1 & 64 \\
\hline Texts & \multicolumn{2}{|c|}{23} & \multicolumn{2}{|c|}{23} & \multicolumn{2}{|c|}{23} & \multicolumn{2}{|c|}{23} & \multicolumn{2}{|c|}{23} & \multicolumn{2}{|c|}{23} & \multicolumn{2}{|c|}{23} \\
\hline
\end{tabular}

In table 2, there are mean and standard deviation scores in terms of dimensions in Text Evaluation Rubric in English Textbooks. According to this table, the mean value of rubric in terms of dimensions was calculated as cohesion 4.00; coherence 3.66; intentionality 3.58; acceptability 2.93 ; contextualization 3.31 ; informativeness 2.38 ; intertextuality 3.11 . These results show that the minimum scores are in informativeness and acceptability dimensions successively. The maximum score is in cohesion dimension. The highest score be obtained from Text Evaluation Rubric in English Textbooks is 4 and the lowest one is 1 . In the light of this reality, the mean of rubric is 3.28 which is high.

\section{Discussion}

In this study, it is aimed to develop "The Text Evaluation Rubric" and to evaluate the texts in the 9th grade English textbooks by means of this rubric. In this context, inter-rater Cohen's Kappa statistics were applied to the data obtained from two raters. The results of this application were evaluated according to table generated by Landis and Koch (1977). This evaluation shows that there is a strong agreement between the raters. The validity of rubric was provided in terms of content, structure and criterion. Moskal and Leydens (2000) state a rubric should be sufficient in terms of content, structure and criterion. In this context, it is seen that the rubric is validity.

The rubric developed in this study can be an alternative measurement tool to evaluate texts' quality in 9th grade English textbooks in addition to the other grades. "The Text Evaluation Rubric" is related to the content and quality of texts. For this reason, it can be an alternative measurement tool.

Güven, Bal and Halat (2014) aim in their study related to textuality criteria to define whether texts in ADA Publishing 5th grade Turkish Textbook are appropriate. It is a qualitative study having been conducted using document analysis. The textuality criteria developed by İşeri (2010) are used in criteria. Analysis show "text-centred textuality criteria" dimension mentions little in every text type (fictional, informative, poem).

Serin and Turan (2015) study textuality in Yunus Emre Turkish Teaching Packet used by Turkish Teaching Centre (as a foreign language). They use document analysis as a research method. 
The texts are examined in terms of type, theme and originality. They tried to detect what kind of literary genre and themes are used, in which level and what kind of literary genre are concentrated on, to what extend there are original texts; whether the text is fit Common European Framework of Reference for Languages.

Uçkun and Onat (2008) study the texts in Quick Step 6 used as English textbook for 6th grades. The results show some texts in the book don't fit the textuality criteria. Mostly texts examining language in a pedagogical way are used instead of using cultural and authentic written and covered texts.

Lüle Mert (2011) evaluated fictional and instructional texts in 8th grade Turkish Textbook in terms of textuality criteria. The writer used the textuality criteria developed by İşeri (2010) in this study. Eight of nineteen texts are fictional and the others are instructional. Only one of these texts (The Memories and Documents About Atatürk) supports the defined textuality criteria. It is detected that there is lack of harmony in the other texts. Being a fictional texts or instructional texts doesn't affect the harmoniousness or inharmoniousness. The readability scores of fourteen texts misfit with the students' level. They are below the students' level. In this context, the texts in 8th grade Turkish textbook don't match the textuality criteria.

Biçer and Çoban (2014) examine the narrative texts being in two different serial books in terms of coherence criteria. They tried to find out the functionality of texts in teaching Turkish as a foreign language. It is a qualitative study using descriptive model. The source of study are fourteen narrative texts selected from "New Hitit Turkish Textbook for Foreigners 1, 2, 3" and seventeen narrative texts selected from "Turkish for Foreigners A1, A2, B1, B2, C1". As a measurement tool, "The Scale of Coherence Evaluation of Narrative Texts" developed by Coşkun (2005) is used. According to the criteria stated in the scale, texts are scored between 1 and 5. The results show that the texts have a moderate level coherence.

\section{Conclusion}

Based on the result and findings of this study, it has been concluded that "The Text Evaluation Rubric" is a reliable and valid instrument and can be used to evaluate the texts in English textbooks. The rubric with seven dimensions can evaluate the different textuality criteria of the texts. It can shed lights on the different point of view of the texts. Generally, the formulas evaluating the readability and understandability of a text are quantitative, however, the rubric developed in this study has qualitative characteristics. In literature, the evaluation of texts by means of formulas isn't sufficient to assess the quality of the texts. So, "The Text Evaluation Rubric" which is related to the quality and content of the texts can be a good alternative. It can be used to measure the quality of the texts used in class environment. The usage of the rubric in different kinds of texts is important for the standardization of the rubric. Especially, it can be used to evaluate the texts in different English textbooks in different grades.

\section{References}

Akbayır, S. (2007). Cümle ve metin bilgisi. Ankara: Pegem Akademi Yayınları.

Aktaş, T. (1996). Çeviri İşlemine Genel Bir Bakış.Ankara: Orsen Matbacılık.

Altunkaya, F. (1987). Cohesion in Turkish: A Survey of Cohesive Devices in Prose Literature. Hacettepe Üniversitesi Sosyal Bilimler Enstitüsü, Yayımlanmamış Doktora Tezi, Ankara.

Ayata-Şenöz, C. (2005). Metinbilim ve Türkçe. İstanbul: Multilingual Yayınları.

Bailey, K. (1994). Methods of Social Research (4th ed.). New York: The Free Press.

Beaugrande, R. A. D., \& Dressler, W. (1981). Introduction to text linguistics. London: Longman Group Company.

Biçer, N., \& Çoban, İ. (2014). Yabancılara Türkçe Öğretimi Ders Kitaplarındaki Öyküleyici Metinlerin Tutarlılık Düzeylerinin Değerlendirilmesi. I. International Eurasian Educational Research Congress, İstanbul.

Brinkler, K. (1988). Linguistic text Analysis (2nd ed.). Berlin: Erich Schmidt.

Can, R. (2012). Ortaögrretim Öğrencilerinin Yazılı Anlatımlarına Paragraf Düzeyinde Bağdaşıklı ve Tutarlılık. Yayımlanmamış Doktora Tezi. Ankara: Gazi Üniversitesi Eğitim Bilimleri Enstitüsü.

Carstens, W. A. M. (1997). Afrikaans text linguistics. An Introduction. Pretoria: JL van Schaik Akademies.

Çeçen, M. A. (2009). Yedinci Sinıf Türkçe Ders Kitaplarındaki Öyküleyici Metinler Üzerine Tutarlıllk Bakımından Bir Araştırma. XXII. Ulusal Dilbilim Kurultayı Bildirileri. Ankara: Yüzüncü Yıl Üniversitesi Yayınları, 12-19.

Cohen, L., \& Manion, L. (1980). Research Methods in Education. London: Groom Helm Ltd.

Coşkun, E. (2005). İlköğretim Öğrencilerinin Öyküleyici Anlatımlarında Bağdaşıkll, Tutarlılık ve Metin Elementleri. Gazi Üniversitesi Eğitim Bilimleri Enstitüsü, Yayımlanmamış Doktora Tezi, Ankara. 
Coşkun, E. (2007). Yazma becerisi. İlköğretimde Türkçe öğretimi. (Ed. A. Kırkkılıç \& H. Akyol). Ankara: Pegem A Yayıncillk.

Creswell, J. W. (1994). Research Design: Qualitative \& Quantitative Approaches. London: SAGE Publications.

De Beaugrande, R. A., \& Dressler, W. U. (1981). Introduction to Text Linguistics. London: Longman.

Demircan, Ö. (1986). Türkçe'de Bağlam İşlevleri ve Bağlayıcılar. Türk Dilbilimi Konferansı Bildirileri, 9-10 Ağustos 1984, (Ed. Ayhan Aksu Koç) İstanbul: Boğaziçi Üniversitesi Yayınları, pp.31-48.

Donnelly, C. (1994). Linguistics for writers. Buffalo: SUNY Press

Fleiss, J. L., \& Cohen, J. (1973). The equivalence of weighted kappa and the intraclass correlation coefficient as measures of reliability. Educational and Psychological Measurement, 33, 613-619. http://dx.doi.org/10.1177/001316447303300309

Gee, J. (1991). "What is Literacy?" In Rewriting Literacy: Culture and the Discourse of the Other. (Eds. Candace Mitchell \& Kathleen Weiler.) New York: Bergin and Garvey, 3-11.

Güllü, N. (1994). "Sessiz Ev" Üzerine Bir Metindilbilim Çalışması. On Dokuz Mayıs Üniversitesi Sosyal Bilimler Enstitüsü, Yayımlanmamış Yüksek Lisans Tezi, Samsun.

Günay, D. (2007). Metin Bilgisi. İstanbul: Multilingual Yayınevi.

Güven, A. Z., Bal, M., \& Halat, S. (2014). 5. sınıf Türkçe ders kitaplarında yer alan metinlerin metinsellik ölçütleri açısından incelenmesi. Ĕgitimde Kuram ve Uygulama, 10(3), 739-763.

Halliday, M. A. K., \& Hasan, R. (1976). Cohesion in English. London: Longman.

Hatch, E. (1992). Discourse and Language Education. Cambridge/New York: Cambridge University Press.

İşeri, K. (2010). Türkçe ders kitaplarındaki metinlerin metinsellik özellikleri. Türkçe ders kitabr çözümlemeleri (ed. Hakan Ülper). Ankara: Pegem Akademi Yayıncılık.

İşsever, S. (1995). Türkçe Metinlerdeki Bağlantı Öğelerinin Metinbilim ve Kullanımbilim Açısından İşlevleri. Ankara Üniversitesi, Sosyal Bilimler Enstitüsü, Yayımlanmamış Yüksek Lisans Tezi, Ankara.

Kan, A. (2007). Performans Değerlendirme Sürecine Katkıları Açısından Yeni Program Anlayışı içerisinde Kullanılabilecek Bir Değerlendirme Yaklaşımı: Rubrik Puanlama Yönergeleri. Kuram ve Uygulamada Eğitim Bilimleri, 7(1), 129-152.

Karatay, H. (2010). Bağdaşıklık Araçlarını Kullanma Düzeyi ile Tutarlı Metin Yazma Arasındaki İlişki. Mustafa Kemal Üniversitesi Sosyal Bilimler Enstitüsü Dergisi, 7(13), 373-385.

Kılıç, V. (2002). Dilin işlevleri ve iletişim. Papatya Yayıncılık, İstanbul.

Koç, A. A. (1992). Eğitim Düzeyinin Anlatı Yapısına Etkisi. Gazi Üniversitesi Gazi Eğitim Fakültesi Dergisi, 8(3), 275-296.

Krippendorf, K. (2004). Measuring the reliability of qualitative text analysis data. Humanities, Social Sciences and Law, 38(6), 787-800.

Landis, J. R., \& Koch, G. G. (1977). The measurement of observer agreement for categorical data. Biometrics, 33, 159-174. http://dx.doi.org/10.2307/2529310

Lüle Mert, E. (2011). 8. Sınıf Türkçe Kitaplarındaki Metinlerin Metinsellik Ölçütlerine Uygunlukları. Dil Dergisi, 153, 7-23. http://dx.doi.org/10.1501/Dilder_0000000153

McCarthy, M. (1991). Discourse Analysis for Language Teachers. Cambridge: Cambridge University Press.

MEB. (2015). Power Up Ortaögretim İngilizce 9. Sinıf Course Book. Devlet Kitapları 1. Bask1, Ankara.

Medina L. B. (2003). The Role of Text Linguistics in the Foreign Language Class. Encuentro Revista de investigación e innovación en la clase de idiomas, 12, 148-156.

Moskal, B. M., \& Leydens, J. A. (2000). Scoring rubric development: Validity and reliability. Practical Assessment, Research \& Evaluation, 7(10).

Neubert, A., \& Shreve, G. (1992). Translation as Text. Kent, OH: Kent State University Press.

Newell, J. A., Dahm, K. D., \& Newell, H. L. (2002). Rubric development and interrater reliability issues in assessing learning outcomes. Chemical Engineering Education, 36, 212-215 
Onursal, İ. (2003). Türkçe Metinlerde Bağdaşıklık ve Tutarlılık. Günümüz Dilbilim Çalı̧̧maları. İstanbul: Multilingual Yayınları.

Oraliş, M., \& Özil, Ş. (1992). Metindilbilimsel yaklaşımla yazınsal bir metni çözümleme denemesi. Dilbilim Araştırmaları. Ankara: Hitit Yayınları.

Özkan, B. (2004). Metindilbilimi, Metindilbilimsel Bağdaşıklık ve Haldun Taner'in "Onikiye Bir Var" Adlı Öyküsünde Metindilbilimsel Bağdaşıklık Görünümleri. Çukurova Üniversitesi, Sosyal Bilimler Enstitüsü Dergisi, 13(1) 167-182.

Şenöz, C. (2005). Metindilbilim ve Türkçe. İstanbul: Multilingual Yayınları.

Serin, N., \& Turan, E. D. (2015). Yunus Emre Türkçe Öğretimi Seti'nde Yer Alan Metinlerin Tür, Tema ve Özgünlük Açısından İncelenmesi. Uluslararası Türkçe Edebiyat Kültür Eğitim Dergisi, 4(3), 1229-1250.

Şimşek, P. (2011). Yabancılara Türkçe öğretiminde okuma metinleri ve yardımcı kitaplar. Afyon Kocatepe Üniversitesi, Yayımlanmamış Yüksek lisans tezi, Afyon.

Stevens, D. D., \& Levi, A. (2004). Rubrics: A practical and equitable tool for instruction and assessment. Paper presented at American Association for Higher Education Assessment Conference, Denver, Colorado.

Stoddart, T., Abrams, R., Gasper, E., \& Canaday, D. (2000). Concept Maps as Assessment in Science Inquiry Learning-A Report of Methodology.International Journal of Science Education, 22, 1221-1246. http://dx.doi.org/10.1080/095006900750036235

Taşıgüzel, S. (2004). İlköğretim Türkçe ders kitaplarında öğretici nitelikteki metinlerdeki eşdizimsel örüntülemelerin görünümü. Ankara Üniversitesi Dil Dergisi, 125, 72- 87.

Tinsley, H. E. A., \& Weiss, D. J. (2000). Interrater reliability and agreement. In H. E. A. Tinsley \& S. D. Brown (Eds.), Handbook of applied multivariate statistics and mathematical modeling (pp. 95-124). San Diego, CA: Academic. http://dx.doi.org/10.1016/B978-012691360-6/50005-7

Toklu, O. (2003). Dilbilime giriş. Ankara: Akçağ Yayınları.

Türk, D. K. (2011). Türkçe sözlük. On birinci basım. Ankara: Türk Dil Kurumu Yayınları.

Uçkun, B., \& Onat, Z. (2008). Yabancıl Dil Kitaplarında Özgün Metin ve Özgün Görev Kullanımının Önemi: Bir Kitap İncelemesi. Gaziantep Üniversitesi Sosyal Bilimler Dergisi, 7(1), 149-164.

Uğur, N. (2012). Metinbilgisi (Ders Notları). Retrieved from nizamettinugur.gen.tr/files/20120406081052.pdf. May 17, 2016.

Ülper, H. (2011). Öğrenci metinlerinin tutarlılık ölçütleri bağlamında değerlendirilmesi. Turkish Studies, 6(4), 849-863.

Zimmaro, D. M. (2004). Developing grading rubrics. Retrieved from http://www.utexas.edu/ academic/mec/research/pdf/rubricshandout.pdf. May 17, 2016. 
Appendix

THE TEXT EVALUATION RUBRIC

DIMENSIONS

Cohesion

Coherence

Acceptability

Contextualization

The title doesn't give information about content.

topic of the text in his/her social environment or culture s/he has. This situation cause that the reader can't load meaning to the text.

Informativeness The text awakens the reader's interest. The text isn't made attractive. The reader can't remember the previous information.

Intertextuality

\section{2(Moderate)}

Some words and

sentences are connected each other meaningfully.

There are lots of misfit sentences. Some sentences are disconnected.

There is a rational pattern between some sentences and paragraphs. There is contradictory information at times.

The message can be partly understood by the readers. However, there are contradictory phrases.

There are few clues helping the reader understand the text easily. However, these phrases aren't sufficient to understand the aim of the text.

There are some words and phrases about the reader's social environment and culture In addition, there are lots of phrases causing not load meaning to the text.

The text is partly made attractive. There aren't any phrases that help the reader remember previous information.

There is a relation between only a few texts. The reader can remember some other texts in some parts of the book.

\section{3(Good)}

The words and sentences are generally related to the text. There are few misfit words and sentences.

There is generally a rational pattern between the sentences and paragraphs.

The message can be generally understood by the readers. The readers can understand the intend of writer. The aim can be elicited by means of phrases used in the text.

There are a few clues helping the reader understand the text easily. The title gives information about the text partly.

The reader can partly visualize the text. There are several expressions that the reader can face his/her social environment.

The text generally awakens the reader's interest by means of pictures and phrases.

There is a triage between most of the texts. The reader can remember most of the texts in some parts of the book.
4(Very Good)

The harmony of words and sentences with text are very good and fluent. There aren't any misfit words.

There is a rational pattern during the text. The words and sentences support content integrity.

The aim of the text is clearly stated with an instruction. The reader can have an idea about the subject wanted to be taught.

There are lots of clues revealing the aim of the text. The reader can analyse the text easily without help. S/he can understand the text using the clues.

The reader can easily visualize the text. There are lots of expressions that the reader can face his/her social environment and culture.

The text awakens the reader's interest with pictures, words, expressions and topics.

All the texts in the book are related to each other. There is a follow-up. The reader can recognize the characters in the texts. visualize another text by means of this text. 